\title{
Landslides Triggered by the April 1997, Tropical Storms in Pohnpei, Federated States of Micronesia
}

by

Edwin L. Harp

and

William Z. Savage

This report is preliminary and has not been reviewed for conformity with U.S. Geological Survey editorial standards or with the North American Stratigraphic Code. Any use of trade, product, or firm names is for descriptive purposes and does not imply endorsement by the U.S. Government.

\section{U. S. Geological Survey Open-File Report 97-696 Denver, Colorado 80225
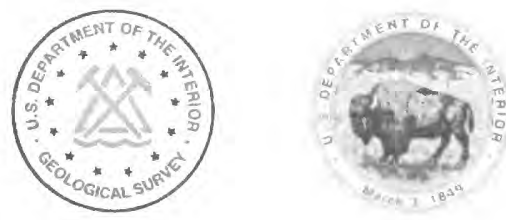


\section{INTRODUCTION}

The combined effects of Super Typhoon Isa and Tropical Storm Jimmy, approximately 1 week apart, triggered over 30 landslides on the island of Pohnpei during the night of April 20-21, 1997. Most of these landslides occurred in the Sokehs District, located along the northwest coast (figs. 1 and 2 (fig. 2 in back)) and resulted in the destruction of 14 dwellings in Sokehs Municipality and 19 fatalities in the villages of Oumoar and Iohl (fig. 2). Precipitation from Super Typhoon Isa on April 11-13 saturated slopes on the island. One week later, over $25 \mathrm{~cm}$ (10 in) of rain from Tropical Storm Jimmy fell during a 4-hour period, triggering landslides that resulted in destruction of homes and loss of life. In this report, we describe the landslides and the geologic materials that failed during the April 1997 storms, present an inventory map of the landslides, discuss the landslide hazards that remain, and make recommendations for future landslide hazard mitigation and studies for assessment of future landslide hazards.

\section{PHYSICAL AND GEOLOGIC SETTING}

The island of Pohnpei lies approximately $800 \mathrm{~km}$ north of the equator $\left(\sim 7^{\circ} \mathrm{N}\right.$., $158^{\circ} \mathrm{E}$.) and experiences a tropical climate. Average precipitation ranges from about $400 \mathrm{~cm} / \mathrm{yr}(160 \mathrm{in} / \mathrm{yr})$ at the coast to almost $900 \mathrm{~cm} / \mathrm{yr}(355 \mathrm{in} / \mathrm{yr})$ in the interior mountains. The island is roughly circular in shape and characterized by steep mountains covered with dense vegetation. Geologically, Pohnpei is a remnant of a large shield volcano built up from the surrounding sea floor by episodic eruptions of slightly alkalic basaltic lavas dating back 9 million years (Spengler and others, 1991). The island lacks extensive coastal alluvial plains around its perimeter because of regional subsidence and sea-level rise (Spengler and others, 1991). The coast lacks beaches and is characterized by basaltic outcrops with adjacent mangrove swamps. A barrier reef surrounds most of the island.

\section{STORMS TRIGGERING THE LANDSLIDES}

Rainfall from Super Typhoon Isa (April 11-13) totaled more than $12.7 \mathrm{~cm}(5 \mathrm{in})$ of rainfall at the National Weather Service station at Kolonia (fig. 2). One week later, after light to moderate rain throughout most of the day on April 20, more than $25 \mathrm{~cm}$ (10 in) fell during a 4-hour period between
10:00 p.m. on the $20^{\text {th }}$ and 2:00 a.m. on the $21^{\text {st }}$ at the Kolonia station. The Kolonia station was the only recording rain gauge on the island at the time of these storms. The gauge is located approximately $5 \mathrm{~km}$ northeast of the center of the area of major landslide concentration and may not have recorded rainfall levels that were as great as those that occurred near Oumoar and Iohl (fig. 2).

Reports of stream levels observed during the storm indicated that maximum precipitation occurred near the area of concentrated landsliding in Sokehs Municipality and that the rainfall decreased with a steep gradient away from this area. Although quantitative data are lacking, it appears that an intense precipitation cell was centered over the area of maximum landslide concentration for several hours. Residents of Oumoar and nearby areas within Sokehs Municipality reported that the landslides that caused the fatalities and property destruction occurred after about 10:30 p.m., April 20.

\section{LANDSLIDES AND THEIR DISTRIBUTION}

\section{General Observations}

Landslides triggered by the combined effects of Typhoon Isa and Tropical Storm Jimmy are shown in figure 2. These landslides occurred in a small area within Sokehs and Kitti Municipalities. A few isolated landslides were located in Net Municipality.

Access to the landslides was limited to reconnaissance by field vehicle, boat, and foot. Approximately one third of the landslides were mapped on foot where examination of their morphology, internal structure, and their rock and soil composition was possible. Note that lack of airphoto coverage from which to map the precise shapes and locations of the landslides resulted in approximate representation on figure 2. Landslides that we visited on foot are mapped more precisely. We feel that we have mapped most of the landslides that were triggered by the storms; however, it is entirely possible that some landslides were hidden by the tropical vegetation and by the inaccessible terrain.

The April 20-21 landslides that we observed were mainly soil and rock slides or rotational slumps initiated by high pore-water pressures within the soil and underlying bedrock that transformed into debris flows as the failed slope materials underwent mixing with additional water and became fluidized during 


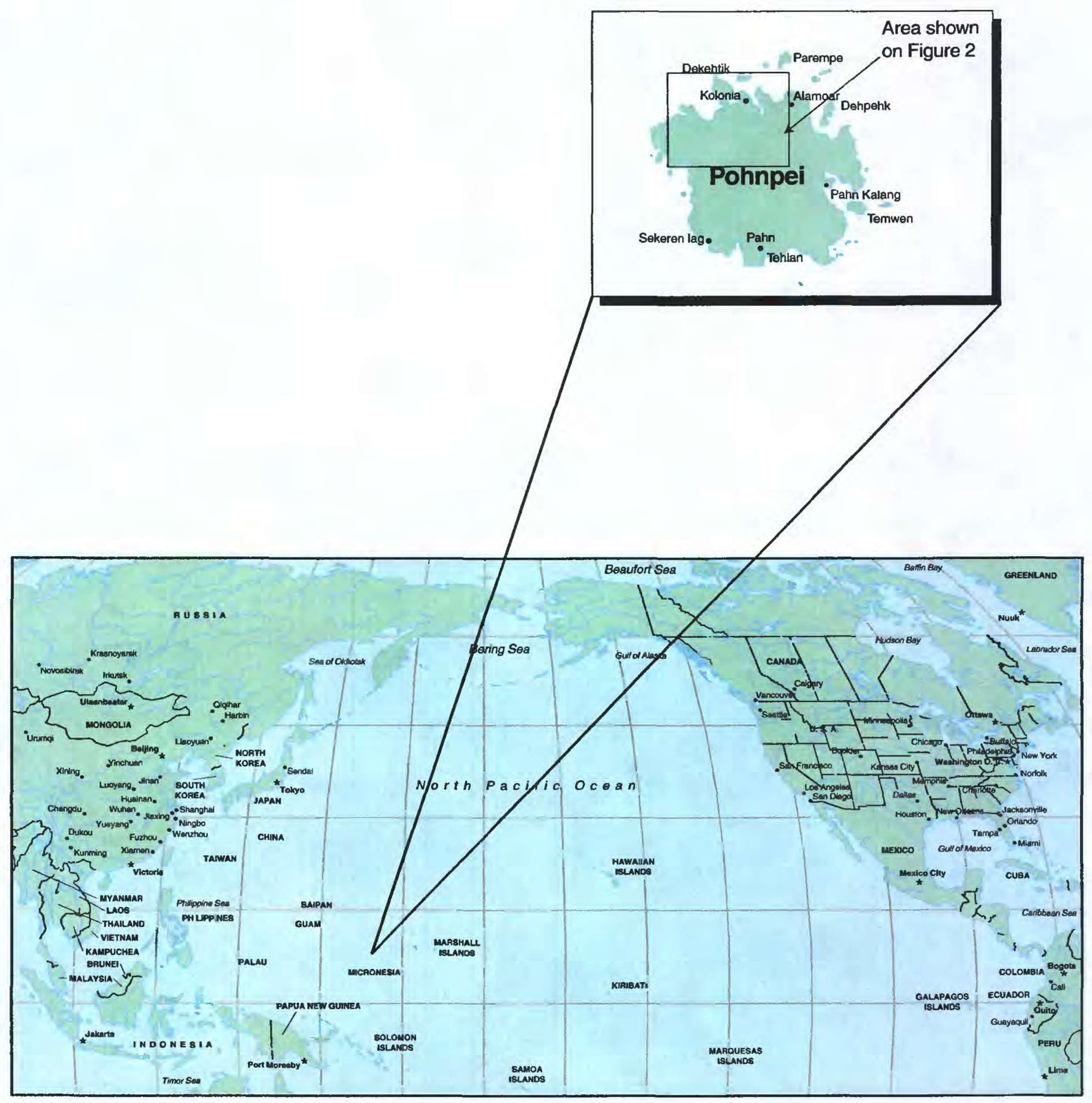

Figure 1. Map of the Pacific Ocean showing the location of the island of Pohnpei, Federated States of Micronesia, and location of figure 2. 
downslope movement. A "debris flow" is a mixture of slope material comprised of at least 20 percent coarse particles (greater than $2 \mathrm{~mm}$ diameter), which have undergone movement similar to that of a viscous fluid, and in which few, if any, shear surfaces are present (Cruden and Varnes, 1996). Once fluidized, debris flows move rapidly downslope like slurries of wet concrete at velocities up to $60 \mathrm{~km} / \mathrm{hr}$, and present great hazards to anything located in their paths.

The initial failures appeared as spoon-shaped rotational slumps and slides with approximately planar failure surfaces (fig. 3). Subsequent to initial failure and movement, most of the soil and rock masses appeared to have undergone fluidization and became debris flows by additional mixing of debris

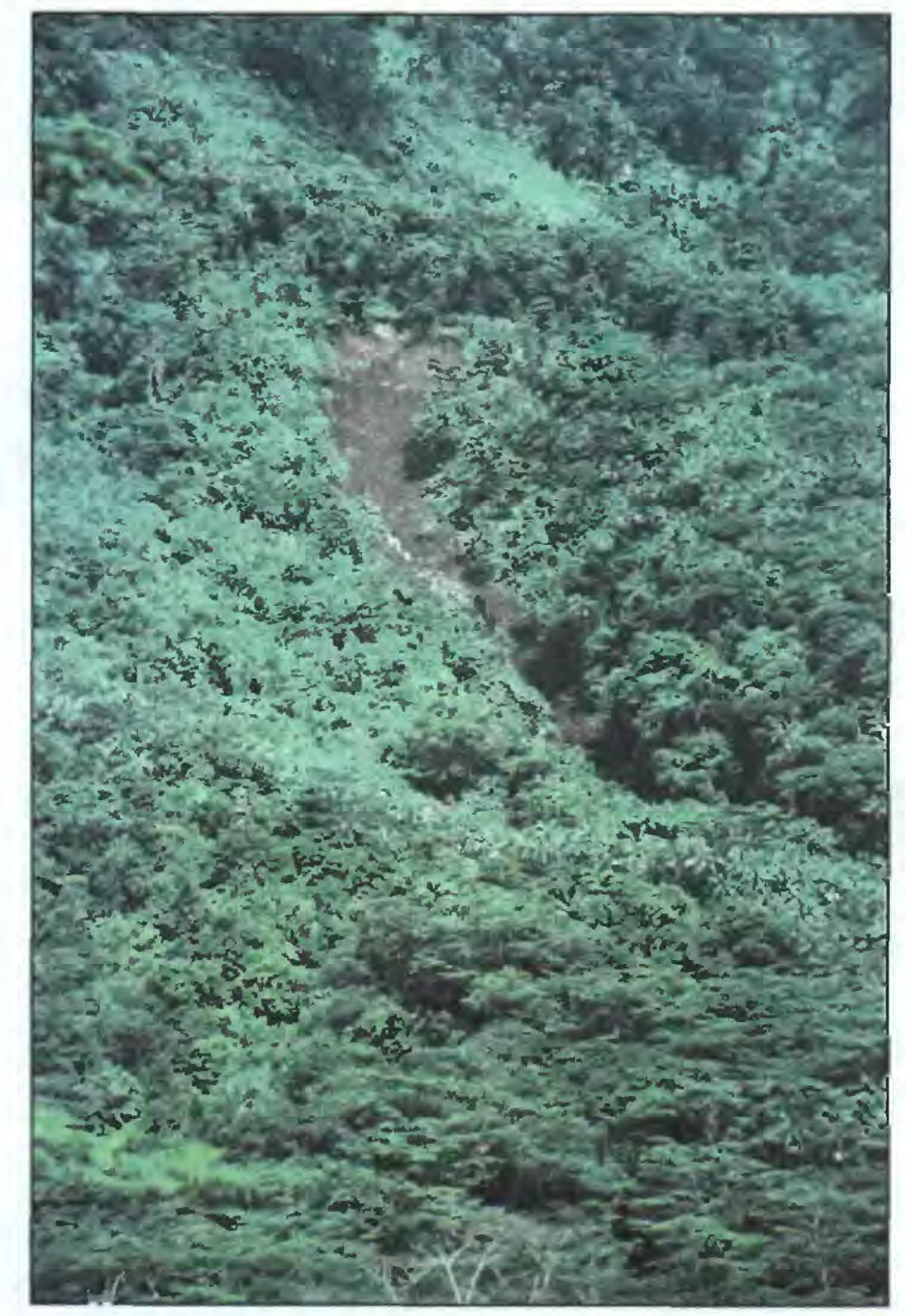

Figure 3. Typical "spoon shaped" rotational slump/debris flow triggered the the April 20-21 tropical storm. and water during the failure process or by intercepting water draining from the failure scarps. In all cases, the landslides that began as rotational slumps or rock and soil slides and subsequently fluidized into debris flows originated on slopes that were $40^{\circ}$ or greater. Most of the landslides originated from areas on slopes that were concave outward, locations where subsurface groundwater flow tends to coalesce or even produce surface flow during saturation caused by extreme rainfall intensity.

Geologic materials exposed in the failure source areas were extremely variable. Basalt flows, volcanic conglomerates and breccias, and sandstones were present within almost every headscarp inspected. Materials varied from extremely hard and fresh to deeply weathered and soft. Debris-flow material contained poorly sorted rock fragments ranging from pebble- to boulder-size diameters. Soil depths were also variable, ranging from tens of centimeters to several meters in depth. The extreme variability of the rocks and soils exposed in the landslide scarps suggest that no single geologic unit is responsible for the April 20-21 landslides in the northwestern corner of the island.

We also looked for vegetation patterns that might be associated with the landslide distribution. We found that most headscarps were located on steep, densely forested slopes. No landslides were associated with deforestation or cultivated plots of land. In fact, slopes devoid of trees and supporting mostly grass and shrubs east of Nan Mall (fig. 2) appear intact.

\section{Landslides at Oumoar and Iohl}

Coalescing debris flows at Oumoar and Iohl were responsible for all of the landslide-related fatalities that occurred on Pohnpei (fig. 2). There were 8 fatalities at Oumoar and 11 at Iohl. In both cases, the destructive flows began at, or about 10:30 p.m. on the night of April 20-21. Residents of Oumoar reported that there were repeated debris-flow episodes along the same path. Several survivors of the first flows that overran dwellings were caught in the paths of later flows as they attempted to rescue those caught in the first. At least three debris-flow episodes were involved in the destruction of the village of Oumoar where debris overran dwellings and swept wreckage and victims into the mangrove swamps that fringe the coast (fig. 4). 


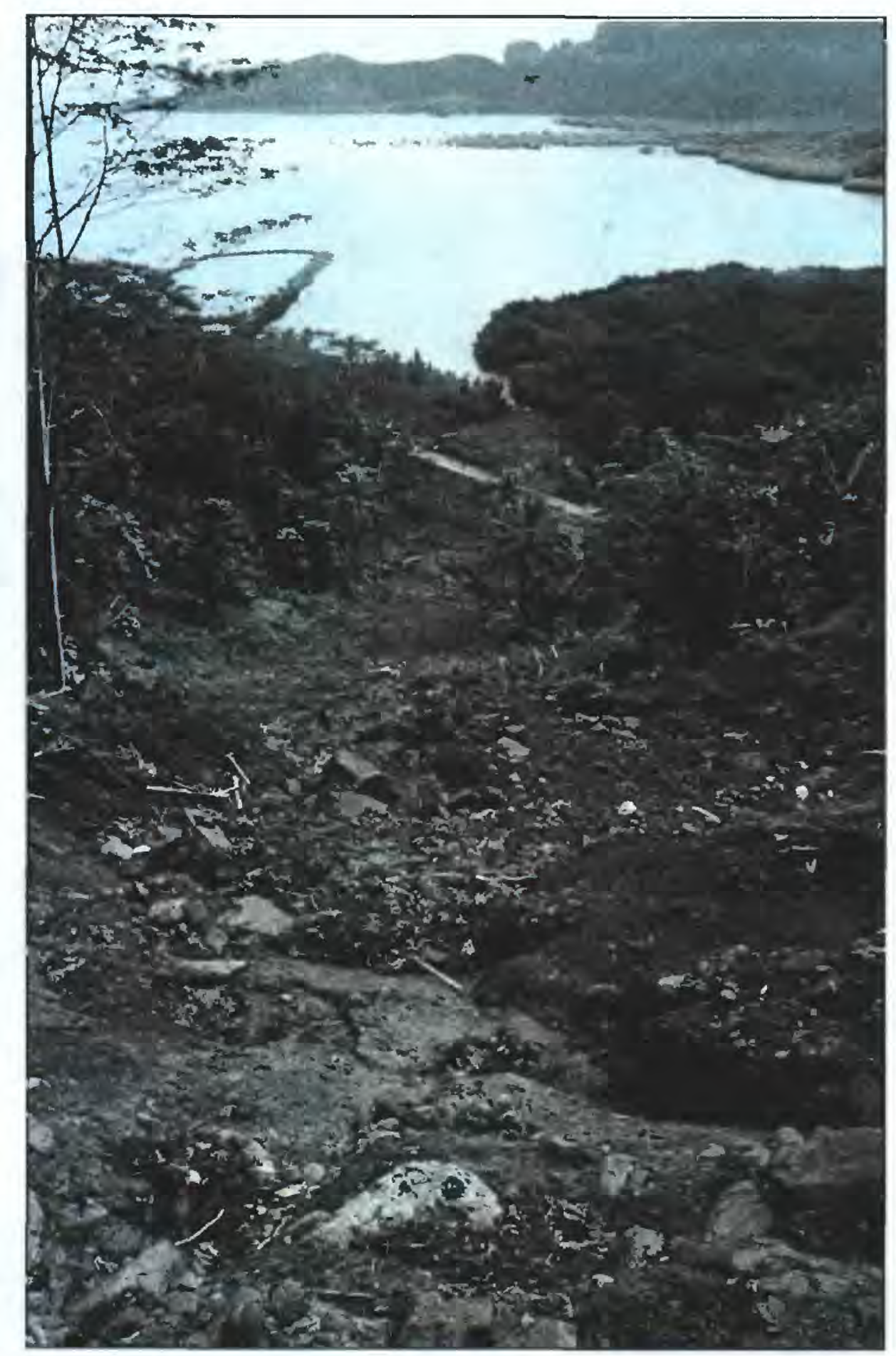

Figure 4. Photo from headscarp area of debris flow at Oumoar looking down the path of flow showing exposed bedrock and large clast size of debris remaining in flow path.

Near the headscarp at Oumoar, slopes were roughly $40^{\circ}$ to the north and northeast, and bedding dips approximately $17^{\circ}$ to the northeast. Soil depths ranged from a few centimeters to $1.5 \mathrm{~m}$, and volumes of individual flows at Oumoar ranged from 2,000 to $7,000 \mathrm{~m}^{3}$. No fractures were observed upslope of the headscarps in the Oumoar area. None of the debris flows examined had well developed lateral levees along their flow paths, as is characteristic of most debris flows. This, and the well developed erosion channels through the landslide debris, suggest that large volumes of water issued from the landslide scarps after initial failure and that the debris flows had high water contents.
The landslide at Iohl was a rotational slump/debris flow approximately $200,000 \mathrm{~m}^{3}$ in volume. Its length from headscarp to its distal end is approximately $800 \mathrm{~m}$. Several fractures existed just above the northeastern portion of its headscarp (as of June 1997; fig. 5) isolating several hundred cubic meters of material that may undergo movement in future high intensity rainfall. However, if this happens, it will provide only a minor amount of additional material to the existing landslide. Near the southwest portion of the headscarp, a block of several hundred cubic meters has moved downslope about $5 \mathrm{~m}$ from its original position on the slope (fig. 6).

The headscarp of the landslide at Iohl faces northnorthwest. At about a third of the distance from the headscarp to the toe, the flow path turns from northwest to approximately due north (fig. 2; fig. 7). About halfway to its toe from the turn in the flowpath, another rotational slump/debris flow of about $10,000 \mathrm{~m}^{3}$ volume merges from the southwest. Fractures extending behind the headscarp of this landslide outline slump blocks of 500 to $1,000 \mathrm{~m}^{3}$ volume. These blocks should be considered unstable and may move in a future episode of intense rain.

The headscarp of the Iohl landslide originated on a slope of about $40^{\circ}$. Geologic materials comprising the landslide debris here are similar to those at Oumoar. Soil thicknesses exposed at the headscarp also vary from about $6 \mathrm{~cm}$ to $2 \mathrm{~m}$. Much of the debris is comprised of large particles ranging from pebble to boulder size. From the geologic map by Spengler and others (1991), it appears that the landslide at Iohl and those at Oumoar have their source areas and flow paths within the older shield-building lavas, which are deeply weathered and interbedded with deposits of volcanic breccia, conglomerate, and sandstone.

\section{Landslide at Nihkewe}

Approximately $0.5 \mathrm{~km}$ northwest of the landslides at Oumoar along the coastal road a rotational slump/ debris flow about $5,000 \mathrm{~m}^{3}$ in volume occurs near Nihkewe (fig. 2). This slump/debris flow still has significant failure material within its headscarp area. In addition, the flow path of this landslide has undercut an adjacent steep slope that may now be more susceptible to future failure events. The debrisflow covered the road and stopped immediately above a house next to and downslope from the road. 


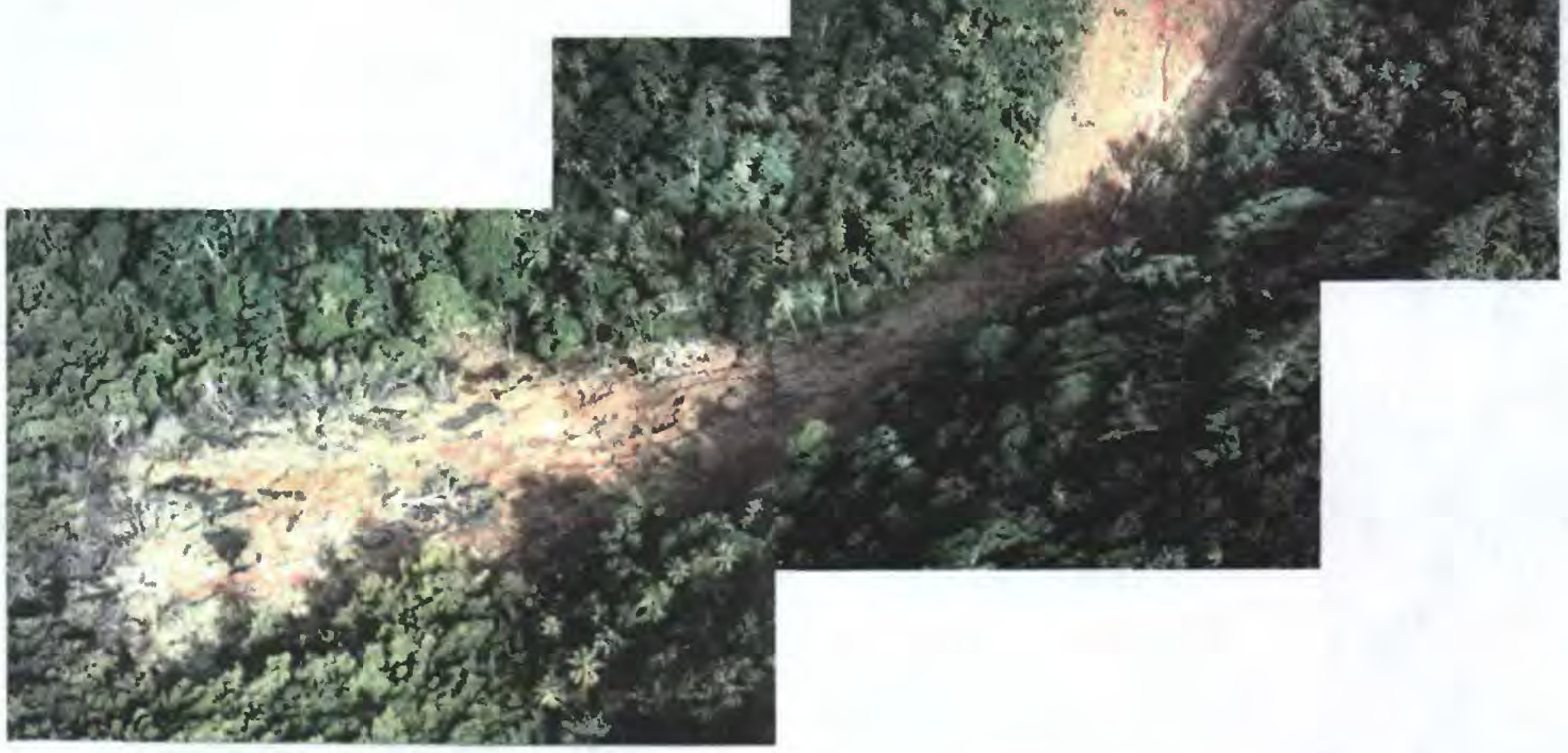

Figure 5. Airphoto mosaic of Iohl slump/debris flow. Arrow in headscarp area indicates position of extension fracture above headscarp. (Photo courtesty of Pohnpei Department of Justice)

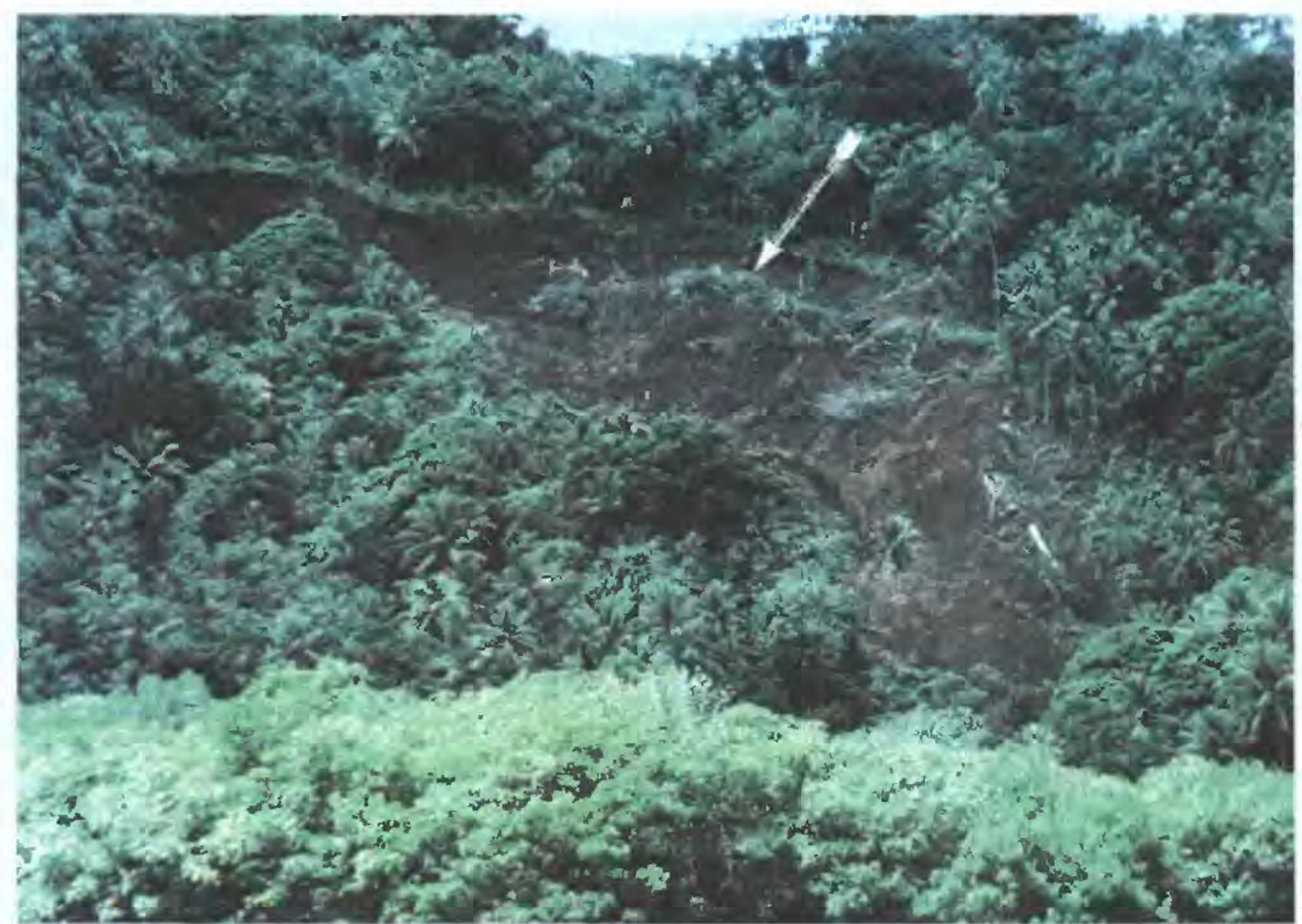

Figure 6. Headscarp area of Iohl landslide showing small slump mass remaining at right center of photo (arrow). 


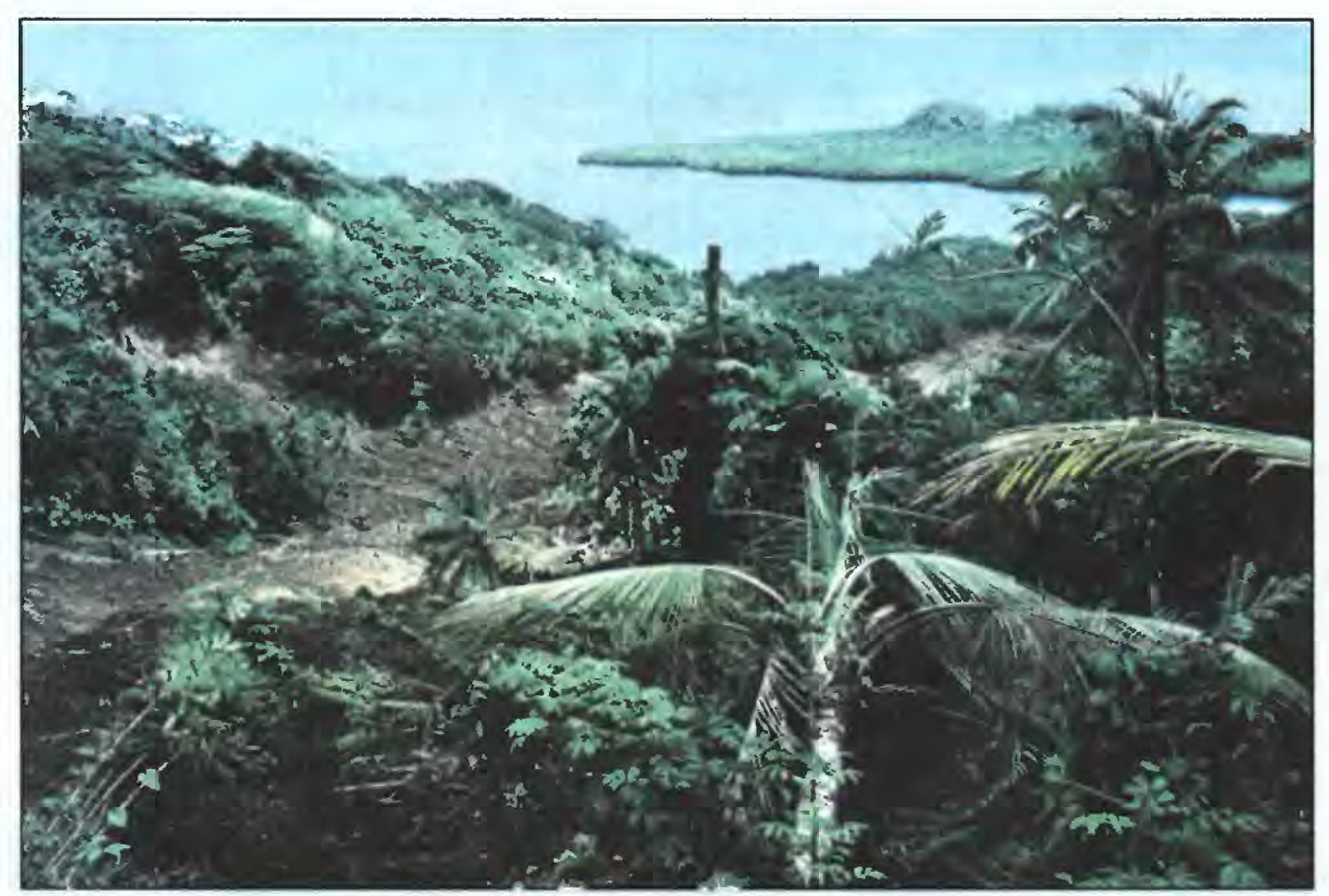

Figure 7. Flow path of debris flow at Iohl showing the confluence of the major flow with a smaller rotational slump at the left of the photo.

\section{Incipient Rotational Slump near Tamwarohi}

About $1 \mathrm{~km}$ southwest of the Iohl landslide, an incipient rotational slump occurred near the small village of Tamwarohi (fig. 2). Discontinuous arcuate fractures formed at the headscarp of the landslide indicate about 40 to $60 \mathrm{~cm}$ of downslope displacement and poorly define an incipient landslide about $100 \mathrm{~m}$ in width and about $120 \mathrm{~m}$ in length parallel to the slope. These fractures are within a weakly-cemented, medium-grained volcanic sandstone. The grains of the sandstone are friable and the "rock" easily broken apart by hand. A residence and a village meeting house located near the toe of the incipient landslide were damaged by cracks that propagated through the building foundations (fig. 8). The fractures in the left flank of the headscarp (looking downhill) crossed a streambed where water could easily travel to the slide surface. This incipient slump is likely to undergo additional movement during future rains and cause further damage to structures located in its path.

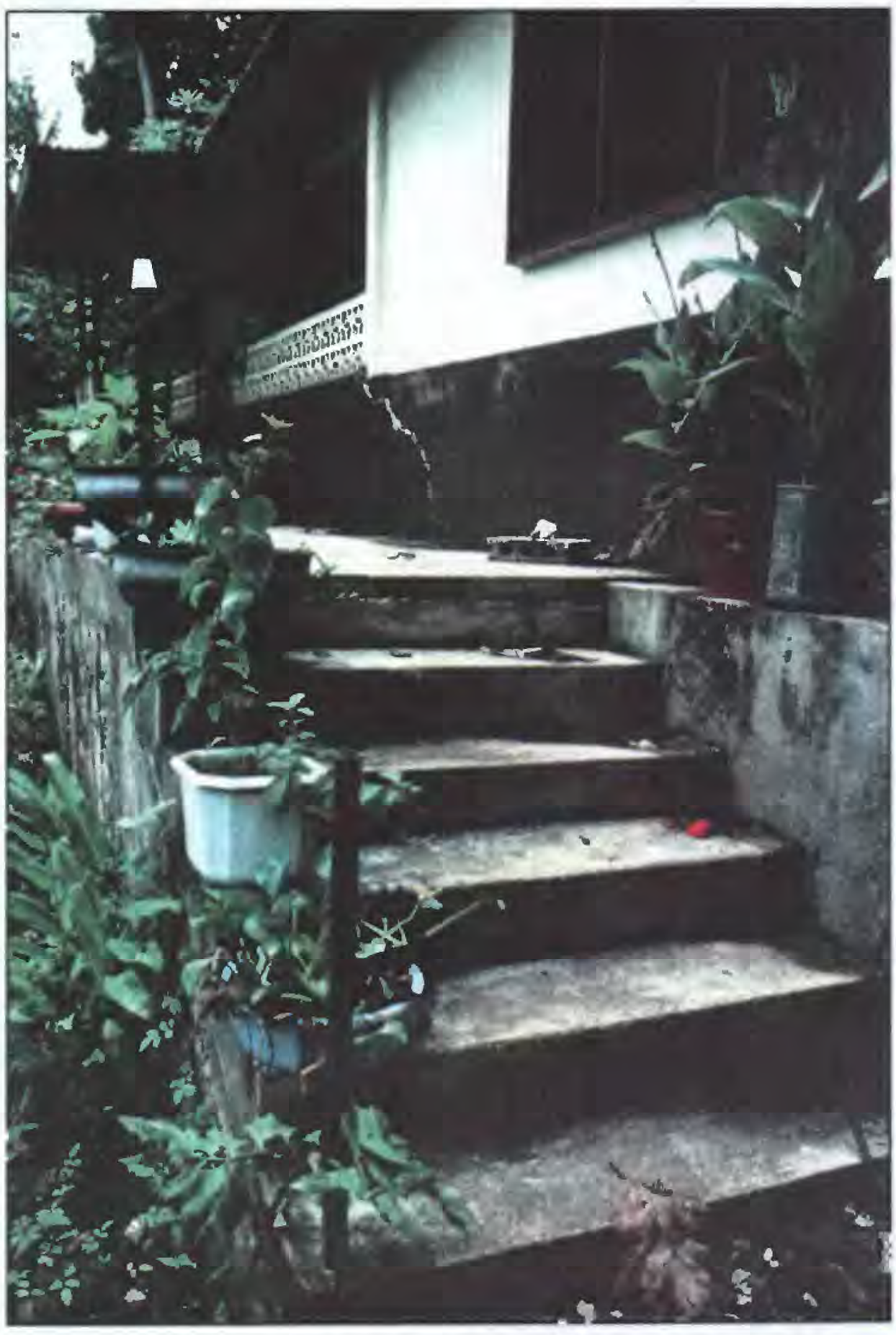

Figure 8. Fractures in foundation of house and steps resulting from movement on incipient rotational slump near Tamwarohi. 
FACTORS RELATED TO LANDSLIDE DISTRIBUTION AND REMAINING HAZARDS

In an event where numerous landslides are formed, two main factors directly influence the landslide distribution: (1) the triggering event and (2) the susceptibility of slope materials to failure.

For Pohnpei, the triggering event was the intense rainfall from Tropical Storm Jimmy on the evening of April 20 and morning of April 21, 1997. Little evidence exists regarding the pattern of rainfall during the evening of April 20 except for verbal accounts. The rain gauge at Kolonia shows over $25 \mathrm{~cm}$ (10 in) of rainfall within a 4-hour time period, an intense, but not record-breaking rainfall. The rainfall that occurred at Oumoar and Iohl in the center of the area of high landslide concentration may have been much higher. Certainly, residents commented that they had never seen rainfall so intense, even on Pohnpei. Reports of stream high-water levels are consistent with the verbal accounts of rainfall and indicate that high streamflow was approximately coincident with high rainfall.

Slope materials within the areas affected by landslides are volcanic rocks, volcanic sedimentary rocks, and their soils. As described above, the rock types exposed in the landslide scarps and their degree of weathering was extremely variable. The exposed rocks ranged from hard, massive basalts and sandstones to friable, intensely fractured, and deeply weathered rocks that were extremely soft and easily broken by hand. The entire hardness and weathering range was exposed in almost every landslide scarp inspected. We saw no landslide scarp that consisted of only a single rock or soil type except for the incipient landslide at Tamwarohi. Therefore, there was no weak or highly susceptible geologic material that was obviously responsible for the landslide distribution. All scarps observed contained some extremely resistant rocks that would not have failed easily. Also, soil depths in the exposed scarps were extremely variable and probably did not play a major part in the failure mechanics of these landslides, as failure depths extended well into bedrock in all of the landslides we observed.

The fact that we did not find highly susceptible geologic units involved in the landslide occurrence on Pohnpei is not surprising. The number of landslides triggered is not particularly high. Highly susceptible geologic materials, such as, recent, unconsolidated volcanic ash deposits or soils derived from weakly cemented sandstones, siltstones, or shales have been documented to have produced hundreds to thousands of landslides in areas similar in size to the area affected on Pohnpei (Harp and others, 1981; Suwa and Okuda, 1985). Considering the high average rainfall for the island, we would expect extremely susceptible geologic units to have been largely removed by erosion unless emplaced or deposited recently. The slopes on Pohnpei have adjusted to high rainfall, and landslides probably do not occur in any great numbers except when these slopes are subjected to abnormal rainfall durations and/or intensities such as those experienced in the storms of April 1997.

As previously mentioned, slopes with little or no forest cover seemed to be largely unaffected. The steep grassy slopes east of Nan Mall discussed above may be revegetated scarps of debris flows that occurred in 1992 (Spengler, personal communication, 1997). If so, the prior removal of the most highly weathered surficial material may have rendered them more resistant to failure in these and future storms. Considering the heights of most of the landslide scarps, which ranged from several meters to over 10 meters into bedrock, root strength, or lack of it, was probably not a significant factor in the location of the landslides.

It is probable that there will be some additional movement of landslide material during future storms. Some of the landslide debris remaining in the flowpaths of various landslides will be redistributed by future rainfall, and several landslides, including that at Iohl, have incipient failures outlined by fractures in the headscarp areas. These incipient failures will probably also undergo additional displacement, but are probably not large enough in volume to mobilize and generate sufficient momentum to reach the limits of the original landslide margins. The landslide at Nihkewe may be an exception. Several thousand cubic meters of debris still remains within its headscarp area. This is a significant volume of material compared to the original volume of landslide debris, and its renewed movement might result in mobilization into another debris flow and generate movement that could conceivably exceed the margins of the present landslide. Also, as mentioned previously, the flow path of this landslide has undercut an adjacent steep slope, which may have reduced its 
stability and increased its probability of failure in future storms.

Aside from the landslide at Nihkewe, most of the landslides do not appear to have significant material nor have incipient failures in their headscarp areas to present a significant ongoing hazard. However, other unfailed steep slopes were not examined. The likelihood of landslide failure is unknown in much of the area because of the thick vegetation covering the slopes. These slopes may have significant but undiscovered fractures signifying incipient failure. Slope areas surrounding accessible recent landslides were observed, but slopes adjacent to more remote landslides were not closely examined.

The incipient landslide in weakly cemented volcanic sandstone near the village of Tamwarohi will probably undergo additional movement during future storms. Fractures present on this slide are likely to intercept surface runoff and provide water to the basal surface of the failure, thus decreasing its stability. It is difficult to predict how much displacement is likely to occur. If displacement of several tens of meters occurs, an adjacent stream could be dammed, posing an additional hazard.

After examining the landslide distribution, individual landslides, the geology and soils of the slopes affected by landslides, the vegetative cover of the slopes, and the mainly qualitative rainfall data from the April 20-21 storm, we conclude that the most significant factor in triggering the landslides was highintensity rainfall and conclude that it is likely that the high concentration of landslides in the Oumoar and Iohl areas in Sokehs Municipality was a direct result of a high-intensity rainfall cell that lingered over that area for a period of about $4 \mathrm{hrs}$. This, together with the fact that no highly susceptible geologic material was associated with the landslides, suggests that the pattern of high rainfall intensity was the controlling factor in determining the landslide distribution. Because the closest rainfall gauge in Kolonia is about $5 \mathrm{~km}$ from the area of high landslide concentration, we have only an approximate idea of the rainfall levels that triggered the landslides. The rainfall intensities at Oumoar and Iohl may have been higher or lower. Judging from verbal reports regarding the perceived intensity of rain there, it was probably higher. Unfortunately, we cannot estimate the rainfall intensities, because no radar images are available for this area of the Pacific which could show patterns of relative intensity.

\section{SUMMARY AND CONCLUSIONS}

The April 20-21, 1997 Tropical Storm Jimmy produced over $25 \mathrm{~cm}$ (10 in) of rainfall within a 4-hr period in Kolonia and possibly greater amounts within the area of high landslide concentration in Sokehs Municipality. This storm triggered more than 30 landslides, several of which caused the destruction of 14 houses in Sokehs Municipality and 19 fatalities in the villages of Oumoar and Iohl. The landslides were mainly rotational slumps and block slides that transformed into debris flows after sufficient movement and mixing with water. The debris flows were extremely fluid and traveled downslope at high speed, possibly reaching velocities as great as $60 \mathrm{~km} / \mathrm{hr}$.

Exposed rock and soils within the landslide scarps revealed a variety of basaltic lavas and sedimentary rocks ranging from deeply weathered and soft to virtually unweathered and extremely hard. This range of lithologies was found in roughly equal proportions within nearly all of the landslides that we examined. Soil depths ranged widely from a few centimeters to several meters in most of the landslide scarps. Failure depths ranged from several meters to more than $10 \mathrm{~m}$ within bedrock. Most debris flow deposits consisted of large volumes of coarse clasts within the pebble- to boulder-size range and lacked well developed levees along the lateral margins of the flow paths, indicating fairly low viscosity and high water content.

The rainfall pattern, although established from highly qualitative observations, suggests a high-intensity cell of precipitation that remained over the area of maximum landslide concentration for approximately $4 \mathrm{hrs}$ from about 10:00 p.m. on April 20 until 2:00 a.m., April 21. The cumulative rainfall from the National Weather Service station at Kolonia, $5 \mathrm{~km}$ from the center of high landslide concentration, was more than $25 \mathrm{~cm}$ (10 in) during this time interval. The high-intensity rainfall of this cell appears to be the main factor causing the landslide distribution. Geologic units, soils, and vegetation type appears to be of secondary importance in the distribution of the landslides. 
Because of the possible future movement of landslide material at Nihkewe and unknown stability conditions of other slopes in the Oumoar and Iohl areas, we think it is prudent to relocate the people that still live in these areas to land less susceptible to landslides, and we commend the Pohnpei state government for their decision to do this. Land near the national government offices in Palikir shown to us as part of the relocation property is on relatively low slopes and away from steep slopes similar to those that failed.

We also recommend that areas where the landslides were concentrated and resulted in damage to people and property remain uninhabited for at least 1 year to determine how the slopes will behave in future storms under high-intensity rainfall. However, permanent relocation is a better alternative. We concur that previously occupied farms can be safely cultivated and maintained during daylight hours when not under intense rainfall. However, living in these areas should be discouraged for the near future.

In review of the events that followed the catastrophic failures, we were impressed with the rescue efforts and efficiency of emergency response teams that searched for victims in the face of continued danger. With the resources available, the location of victims and recovery of bodies for burial was remarkable.

The tragic results of the April landslides make clear the destructive impact that landslides can have on society. Therefore, we recommend that the following steps be taken to learn from this catastrophic event and to enhance mitigation of future landslide hazards on Pohnpei:

- Obtain post-landslide aerial photography of the landslide-affected area of the island at a scale of $1: 12,000$ or larger to accurately document the landslide occurrence and produce a landslide inventory map that can be digitized for Geographic Information Systems (GIS) analysis.

- Obtain any additional rainfall information that may exist on the island to gain a better assessment of rainfall distribution during the storm that triggered the landslides.

- Deploy additional rain gauges to provide more detailed patterns of future intense rainfall events. These rain gauges need not be automated gauges.
They can be manual gauges read at hourly intervals during particularly intense rainfall periods. Such gauges are inexpensive, easy to read, and can be distributed to all the villages on the island. It is entirely possible that 50 or more gauges could be deployed and, if diligently read and recorded, can provide extremely detailed and useful rainfall information in future storms that may trigger landslides and flooding.

- Digitize the geologic and soil-survey maps of the island and construct a digital elevation model (to derive a slope map) from existing topographic maps for analytic comparison with the landslide distribution in this and future landslide events.

With these items, initial steps can be taken to construct a landslide hazard map of the area where landslides were concentrated. Of the above items, the aerial photography of the landslide-affected areas is the most important as it will allow the development of an accurate inventory map of the April landslides. Establishing additional rainfall-recording stations is critical to evaluate the effects of future rainfall intensity and duration patterns in triggering landslides and to establish rainfall thresholds (in terms of intensity and duration) at which landslides are initiated on Pohnpei. If a dense network of rain gauges can be deployed to record future rainfall, GIS-based analyses can be made in the future to quantitatively assess the relative influence of factors such as geology, soils, vegetation, slope, and rainfall on the generation of landslides and thus provide the foundation for constructing landslide hazard maps for Pohnpei.

\section{ACKNOWLEDGEMENTS}

This reconnaissance was performed as part of a reimbursable support agreement for the Department of the Interior, Office of Insular Affairs. We are indebted to the Department of Justice of the state of Pohnpei who provided us with the assistance of Nickontro Johnny, an employee of the Bureau of Social Affairs who is extremely familiar with the island and its residents. Under his guidance, we visited the sites of the landslides that were the most damaging to people and property. With his help, we were able to obtain much helpful information from residents who were eyewitnesses to the landslides. 


\section{REFERENCES}

Cruden, D.M., and Varnes D.J., 1996, Landslide types and processes in Turner, A.K., and Schuster, R.L., Landslides-Investigation and Mitigation:

Transportation Research Board Special Report 247, Washington D.C., p. 36-71.

Harp, E.L., Wilson, R.C., and Wieczorek, G.F., 1981, Landslides from the February 4, 1976, Guatemala earthquake: U.S. Geological Survey Professional Paper 1204-A, 35 p., 2 pl.
Spengler, S.R., Peterson, F.L., and Mink, J.F., 1991, Geology and hydrogeology of the island of Pohnpei, Federated States of Micronesia: Water Resources Research Center Technical Report No. 189, University of Hawaii at Manoa, 79 p.

Suwa, H., and Okuda, S., 1985, Measurement of debris flows in Japan: Proceedings of the Fourth International Conference and Field Workshop on Landslides, Tokyo, p. 391-400. 


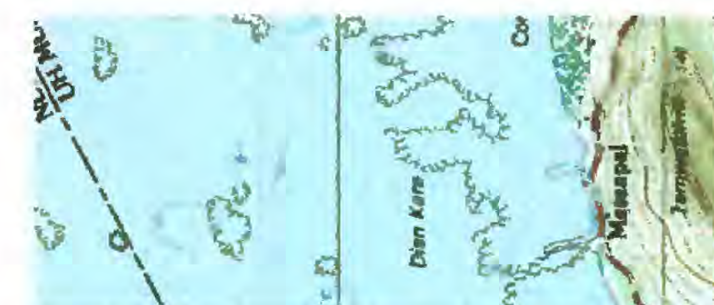

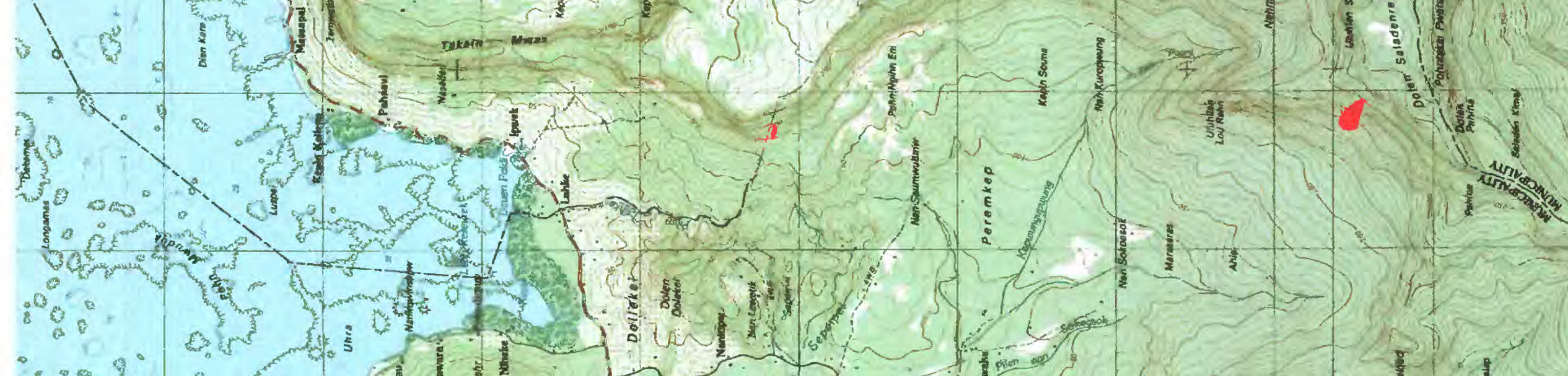

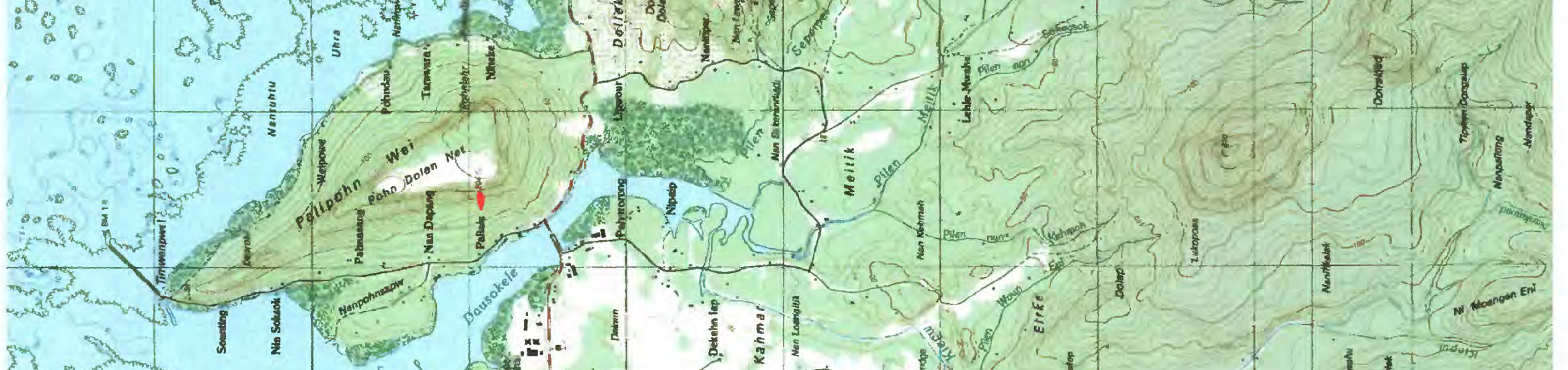

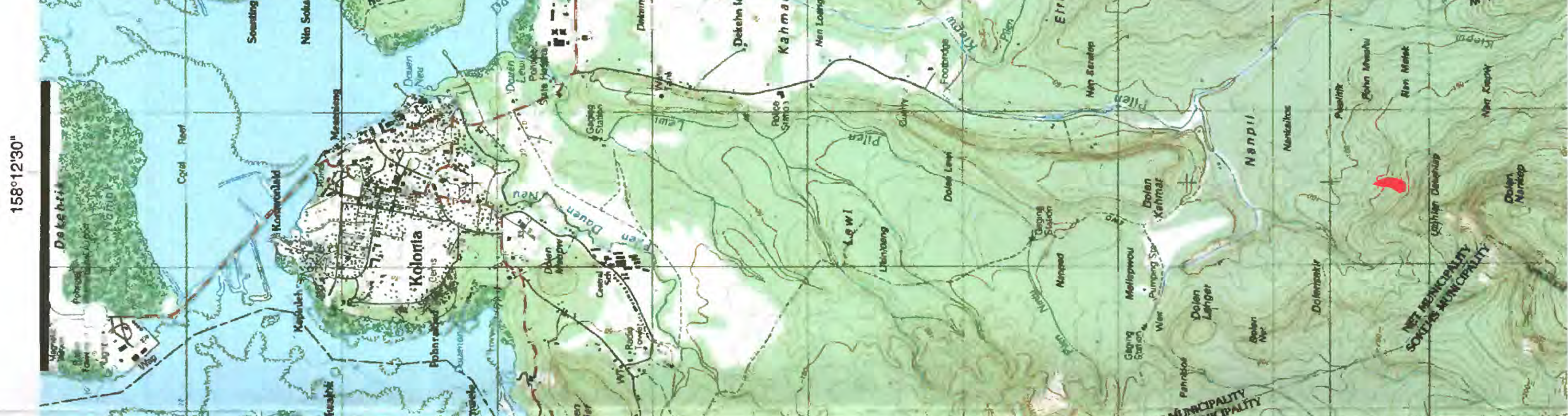

st $x^{2}-2,1+2$

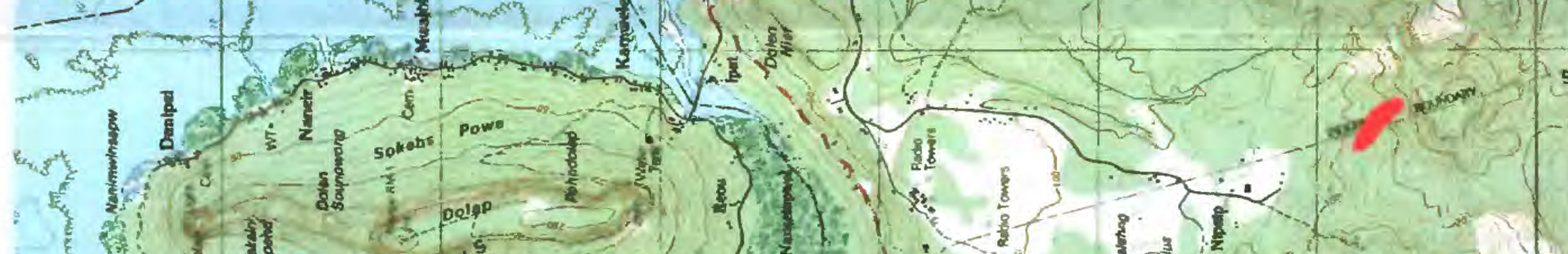

$7\left(y^{3}\right)$ bी

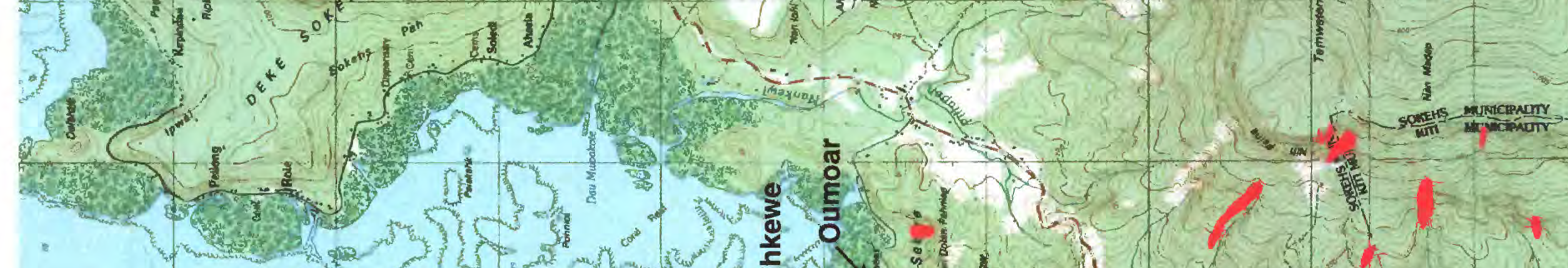
- entsing

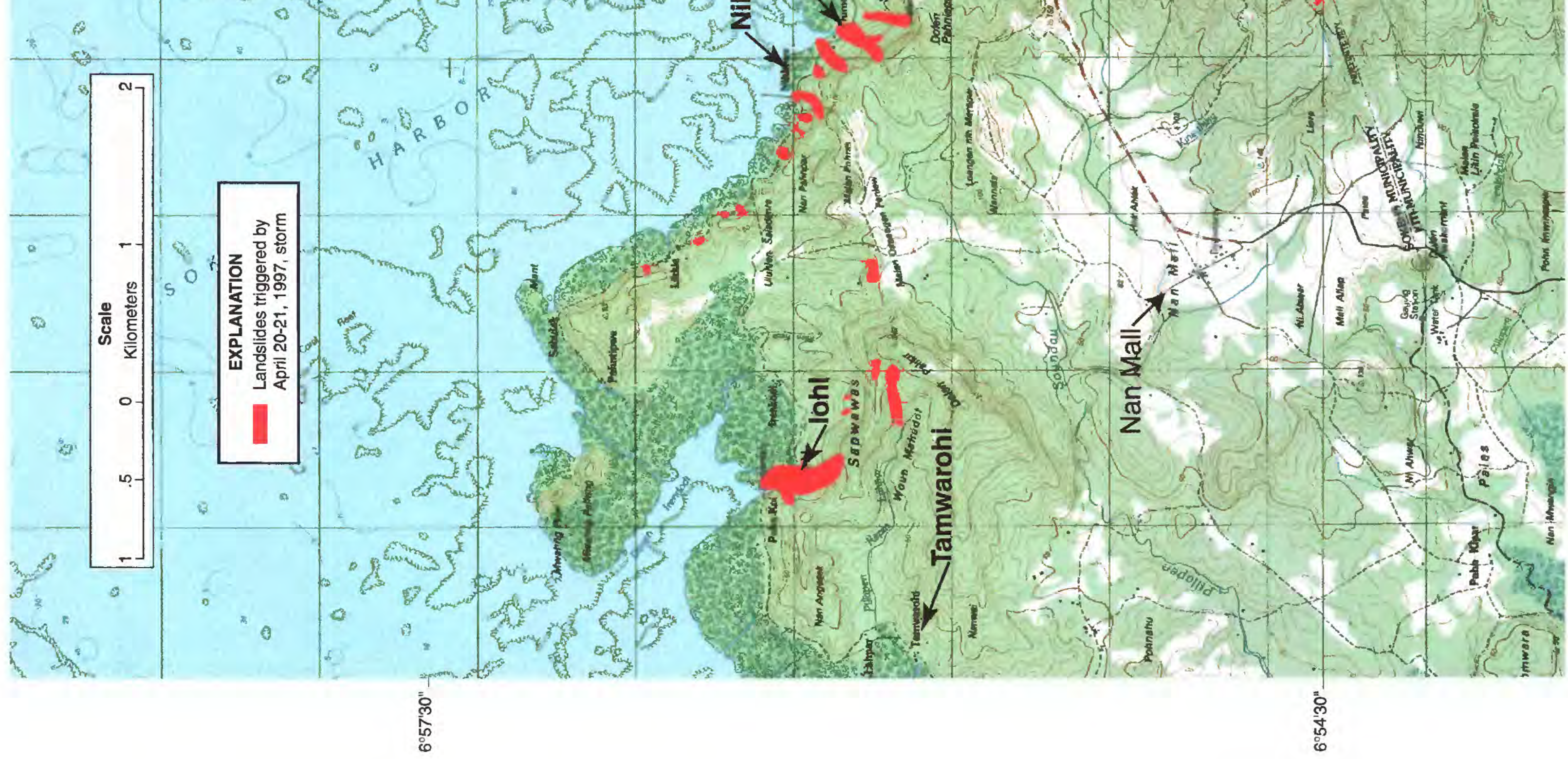

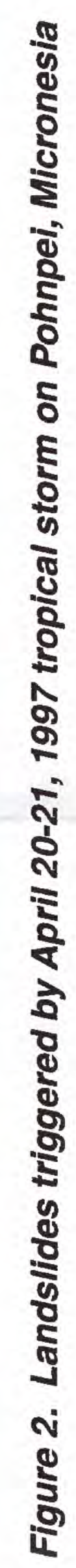

